AperTO - Archivio Istituzionale Open Access dell'Università di Torino

\title{
Internal and external factors in innovation persistence
}

\section{This is the author's manuscript}

Original Citation:

Availability:

This version is available http://hdl.handle.net/2318/134344

since 2016-01-25T08:49:11Z

Published version:

DOI:10.1080/10438599.2012.708135

Terms of use:

Open Access

Anyone can freely access the full text of works made available as "Open Access". Works made available under a Creative Commons license can be used according to the terms and conditions of said license. Use of all other works requires consent of the right holder (author or publisher) if not exempted from copyright protection by the applicable law. 


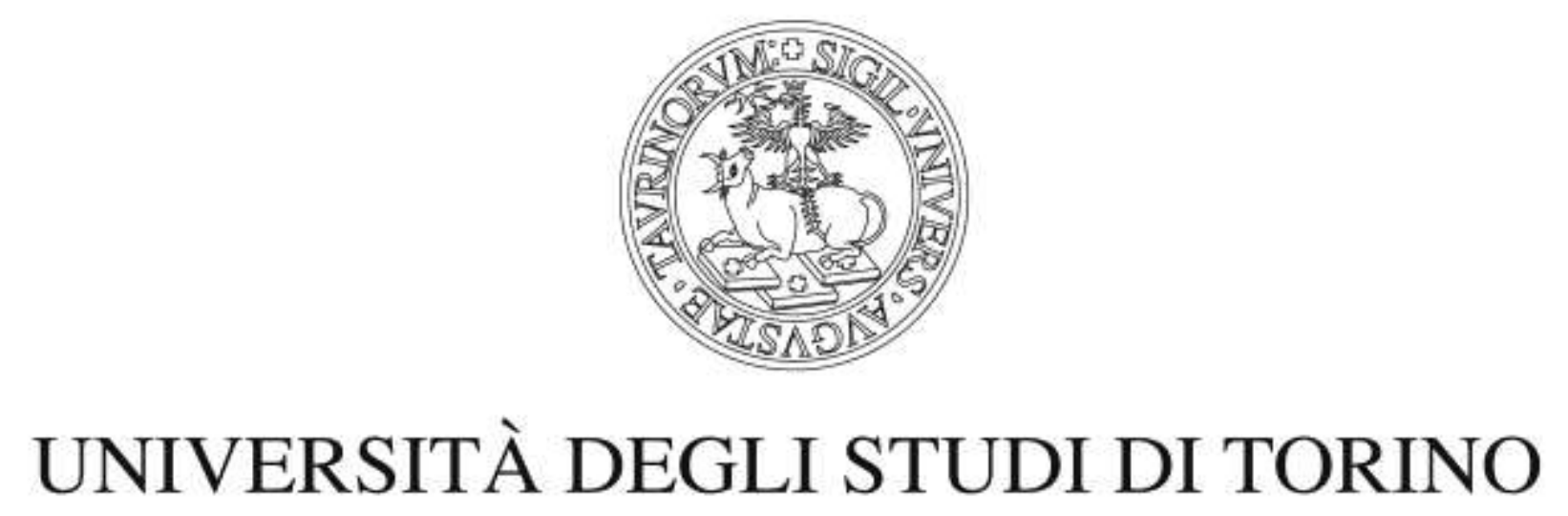

Questa è la versione dell'autore dell'opera:

Economics of Innovation and New Technology, volume 22 e fascicolo 3, 2013, DOI 10.1080/10438599.2012.708135

La versione definitiva è disponibile alla URL:

http://www.tandfonline.com/doi/abs/10.1080/10438599.2012.708135\#.U1YW2FV_uhs 


\title{
INTERNAL AND EXTERNAL FACTORS IN INNOVATION PERSISTENCE ${ }^{1}$
}

\author{
Cristiano Antonelli \\ Dipartimento di Economia, Università di Torino \\ BRICK (Bureau of Research on Innovation, Complexity and Knowledge), Collegio Carlo \\ Alberto.

\section{Francesco Crespi} \\ Corresponding author: crespi@uniroma3.it \\ Dipartimento di Economia, Università Roma Tre \\ BRICK (Bureau of Research on Innovation, Complexity and Knowledge), Collegio Carlo \\ Alberto.

\section{Giuseppe Scellato} \\ Dipartimento di Ingegneria Gestionale e della Produzione, Politecnico di Torino \\ BRICK (Bureau of Research on Innovation, Complexity and Knowledge), Collegio Carlo \\ Alberto.
}

\begin{abstract}
This paper contributes the analysis of the persistence of innovation activities, as measured by total factor productivity (TFP), and explores its internal and external determinants stressing its path-dependent characteristics. The external conditions, namely the quality of local knowledge pools and the strength of the Schumpeterian rivalry, along with the internal conditions (the actual levels of dynamic capabilities, as proxied by wage levels and firm size) exert a specific and localised effect upon the persistent introduction of innovations. A Multiple Transition Probability Matrixes (MTPMs) approach has been implemented to capture the contingent effects of external effects on long-term innovation persistence. The empirical analysis of the dynamics of firm level TFP for a sample of approximately 7000 Italian manufacturing companies observed during the years 1996-2005 is based on both the comparison of different transition probability matrixes and on dynamic discrete choice panel data models. The evidence provided by the test of MTPMs in sub-periods suggests that innovation persistence is path-dependent, as opposed to past-dependent.
\end{abstract}

\section{JEL CLASSIFICATION: O31, C23, C25, L20}

KEY-WORDS: KNOWLEDGE CUMULABILITY; KNOWLEDGE EXTERNALITIES; INNOVATION; PERSISTENCE; SEQUENTIAL MARKOV CHAINS; PATH DEPENDENCE; TFP.

\footnotetext{
${ }^{1}$ The authors acknowledge the financial support of the European Union D.G. Research with the Grant number 266959 to the research project 'Policy Incentives for the Creation of Knowledge: Methods and Evidence' (PICK-ME), within the context Cooperation Program / Theme 8 / Socio-economic Sciences and Humanities (SSH), of the Collegio Carlo Alberto, of the University of Torino, of the Politecnico di Torino and of the Roma Tre University. The comments and suggestions of two anonymous referees are also gratefully acknowledged. The usual disclaimers apply.
} 


\section{INTRODUCTION}

According to the conventional economic wisdom, innovation is an exogenous random shock. The economics of innovation impinges upon the view that innovation is the deliberate and intentional result of the ability of firms to generate new knowledge and to apply it to new products, processes, organisational methods, combinations of inputs and new markets (Nelson and Winter, 1982; Dosi et al. 1988; Fagerberg et al., 2005).

This approach leads to two quite distinct explanations of innovation persistence. The first, consistent with the resource-based theory of the firm, contends that innovation persistence is the result of intrinsic characteristics of the firm. Innovation capabilities are time-invariant endowments that display their effects. Innovation persistence is fully driven by the initial allocation of innovation capabilities: firms are able to learn to learn (Penrose, 1959; Stiglitz, 1987; Teece and Pisano, 1994: Langlois and Foss, 1999).

The second explanation posits that innovation persistence is a pathdependent process in which the probability of introducing an innovation at time $\mathrm{t}$ is influenced by the introduction of an innovation at time $\mathrm{t}-1$. However, the transition probability might change over time because of the effects of contingent events and specifically because of changing levels of knowledge externalities. The generation of new knowledge and the introduction of innovations are the conditional results of a creative and localised reaction that occurs when firms face unexpected events in both factor and product markets. Some contextual and ever-changing conditions, however, are necessary to make the reaction creative so that it leads to the introduction of an innovation, as opposed to an adaptation. In the latter case, the lack of contextual characteristics would enable firms to change techniques in a given technical space but would not lead to the introduction of a productivity-enhancing novelty (Schumpeter, 1947).

To contend with unexpected events in factor and product markets and the subsequent out-of-equilibrium conditions, firms try and mobilise their internal stocks of knowledge through learning processes. The probability that the firm's reaction leads to the successful introduction of an innovation depends on access to available external knowledge. In other words, the firm's reaction to unexpected events becomes creative when the competence 
accumulated through internal learning processes and access to external knowledge pools combine. (Antonelli, 2008 and 2011).

According to this view, proximity, knowledge governance and the communication channels that link firms might enhance the process of knowledge generation, favouring interactions among agents with diverse knowledge bases. Indeed, firms cluster mainly for these specific reasons (Swann et al., 1998; Baptista and Swann, 1999). Long-distance coordination among agents and knowledge interactions can also be realised through organised proximity (Rallet and Torre, 2005). In this context, knowledge governance mechanisms and the characteristics of knowledge structure are particularly relevant (Quatraro, 2012).

Beginning with the seminal contribution by Griliches (1979), a rich and detailed array of empirical studies confirm the pervasive role of technological spillover in favouring the economic performances of clustered firms in terms of output, employment, labour productivity and total factor productivity. The subsequent literature has interpreted these empirical findings as reliable clues to assessing the positive effects of knowledge externalities on the rate of introduction of technological changes by firms that are able to use external knowledge as an input in their own innovation processes (Acs et al., 2002; Fritsch, 2002 and 2004; Fritsch and Franke, 2004).

Building on this literature, we advance the hypothesis that innovation persistence is path-dependent, as opposed to past-dependent, because it is the result of not only the internal characteristics of firms, as the resource-based theory of the firm claims, but also the changing characteristics of the context in which firms are located. Knowledge externalities are strictly necessary for firms' reactions to become creative. When and if the characteristics of the context change, the results of the innovative effort also change. Hence, innovation persistence can no longer be regarded as the result of an intrinsic capability of the firm that behaves as an endowment, given once and lasting forever; rather, it should be regarded as the conditional result of a systemic and interactive process that keeps changing over time (Antonelli and Scellato, 2012).

The present paper builds on the recognition that external technological knowledge represents an augmenting and facilitating factor in the introduction of technological innovations and extends this concept by arguing that external knowledge is a key factor in determining a pathdependent innovation persistence characterised by contextual and conditional recursive feedbacks. The paper elaborates the hypothesis that the introduction of innovations is the persistent, emerging property of an economic system characterised by knowledge cumulability and 
complementarity both inside and outside of firms. Indeed, the introduction of new technologies and new organisational methods affects the system in two ways: it engenders further series of unexpected events and Schumpeterian rivalry and makes available new knowledge spillovers that add to the existing stock of external knowledge.

Knowledge cumulability consists of the inter-temporal, diachronic indivisibility of knowledge. It is well-known that the arrovian economics of knowledge assumes that knowledge is characterizised by indivisibility and non-exhaustibility. Knowledge vintages add on and build up a stock of knowledge that is not exhausted because of repeated use.

Indivisibility manifests in cumulability and complementarity among the different units of knowledge. In parallel to the units of knowledge that are internally possessed by each agent, external units of knowledge possessed by other agents also play a central role. The generation of new knowledge is possible only by 'standing on the shoulders of giants', that is, through access to and use of the existing stock of knowledge. The existing knowledge base, however, is located both inside each firm and in the other agents that belong to the same system (Colombelli and Von Tunzelmann, 2011).

As Peter Swann has convincingly shown, the structure of the system changes endogenously because of the changing modes of interaction among firms, their entry and exit, and their growth. The introduction of innovations is itself a major factor of change in the architecture of the system. The external conditions in which firms are embedded are simultaneously a consequence and a cause of the recursive feedback that supports the persistence of innovation activities (Swann et al., 1998; Baptista and Swann, 1998 and 1999; Beaudry and Swann, 2009).

Internal and external knowledge cumulability affect the dynamics of economic processes because the knowledge base that each firm can access and use internally and externally shapes the probability of the generation of new knowledge. Such effects can change over time because the rates of accumulation and the conditions of access are not fixed. Inventions and scientific breakthroughs can make some portions of the stock of knowledge obsolete. Changes in the structure of interactions and transactions can modify access to external knowledge. As such, the effects of internal and external knowledge cumulability are typically path-dependent rather than past-dependent. In the former case, the effects of hysteresis are qualified and shaped by the contingent changes that occur in the process. In the latter case, the process is shaped by the initial conditions only. The dynamics of the process are influenced by a weak irreversibility that allows changes in the 
process to alter both the rate and the direction of the dynamics with typical path-dependent effects (David, 1997 and 2007).

With this approach in the background, the aim of this work is threefold. First, we contribute to the literature on the persistence of innovation by providing an empirical analysis based on total factor productivity measures. Second, we qualify the characteristics of this persistence and explore its external determinants by specifically examining the role of regional context and the characteristics of the product markets in shaping this process. Third, we discuss in detail the methodological and theoretical implications of the use of TPMs with reference to Markov chains theory.

The remainder of the paper is structured as follows. Section 2 reviews the literature on this matter. Section 3 outlines the hypotheses and the research design of this study. Section 4 presents the econometric evidence. The conclusion summarises the main results.

\section{PRIOR RESEARCH ON INNOVATION PERSISTENCE}

In a special issue of the International Journal of Industrial Organization dedicated to the economics of path dependence, Malerba, Orsenigo and Peretto (1997) pave the way to the analysis of the persistence of innovation activities now explored by a growing literature, which is synthesised in Table 1.

[Table 1 about here]

Earlier studies can be grouped into two subsets: those that build on the analysis of large samples of patents and empirical studies that use data from innovation surveys. The persistence of innovation has been addressed by studying various factors, such as technological specialisation (Malerba et al. 1997), cross-country and cross-sector evolution (Cefis and Orsenigo 2001; Raymond et al., 2010; Clausen et al., 2011), the empirical properties of the distribution of persistence (Cefis 2003) and the diverse typologies of innovative activities (Roper and Hewitt-Dundas, 2008; Peters, 2009; Martínez-Ros and Labeaga, 2009; Le Bas et al., 2011; Antonelli et al., 2012). Some convergent conclusions appear to have been reached by previous studies, although they have emerged from different contexts. In particular, both innovators and non-innovators showed a strong tendency to remain within their states. The evidence shows that the degree of persistence varies according to the innovation indicator adopted (Duguet and Monjon, 2004). While the works that have used patents as indicators suggest that persistence is weak, exhibiting strong values only in the case of top patentees, empirical 
analyses based on survey data found stronger evidence of innovation persistence.

Several factors have been associated with the presence of persistence in innovative activities. Among these factors, firm size, profitability and the intensity of $\mathrm{R} \& \mathrm{D}$ activities were shown to be crucial, confirming the hypothesis that the accumulation of knowledge over time tends to induce a state dependence in innovative behaviour and that the availability of internal funds enhances the ability to continuously engage in innovation (Cefis and Ciccarelli, 2004; Latham and Le Bas, 2006; Peters, 2009).

The evidence suggesting that $\mathrm{R} \& \mathrm{D}$-based innovation activities tend to be associated with higher persistence appears to be of particular importance because it helps to explain two important results emerging from the previous literature. First, several contributions highlighted that innovation persistence is stronger in high-tech, science-based industries where R\&D activities are concentrated (Raymond et al., 2010; Clausen et al., 2011). Second, when different innovation output indicators have been considered, product innovation, which is very often linked to R\&D investments (Crespi and Pianta, 2007), tends to be characterised by higher persistence than process innovation (Martínez-Ros and Labeaga, 2009; Antonelli et al., 2012). In this respect, the complementarities among different types of innovation activities emerged as crucial in shaping different patterns of persistence (Clausen et al., 2011 and Antonelli et al., 2012), including the case of organisational innovation.

In the reviewed studies, attention has been paid primarily to internal factors that consider persistence to be the result of firm characteristics, while the role of external knowledge and local context in shaping innovation persistence is almost totally neglected. In this respect, our paper adds to the previous literature because it is the first attempt to consider external factors in determining innovation persistence. Building on previous analyses showing that successful innovative activity is more likely to occur within strong industrial regions (Baptista and Swann, 1999; Swann, Prevezer and Stout, 1998), we claim that the degree of access to the stock of knowledge of other agents in the system is likely to play a major role in assessing innovation persistence. The persistence of innovation is then determined by the twin effects of knowledge cumulability internal to firms and external to firms but internal to their localized context of action. Access to the knowledge base outside of each firm is necessary for the introduction of technological innovations. At the same time, however, external knowledge provided by the location continues to change over time, albeit slowly. The architecture of interactions and transactions that are the carriers of knowledge externalities change gradually over time as a result of the growth 
performances of firms, their entry, decline and exit and ultimately the introduction of innovations. (Antonelli and Scellato, 2012).

Furthermore, because evidence of persistence has been shown to be dependent in part on the specific innovation activity scrutinised, we will use total factor productivity growth to obtain a general measure of the extent to which innovation is persistent at the firm level. The empirical tests will develop the Transition Probability Matrix (TPM) methodology implemented by many authors, such as Cefis and Orsenigo (2003), Cefis (2005), Peters (2009), David and Rullani (2008) and Antonelli et al. (2012). In particular, we propose an approach that considers observing different TPMs for specific sub-periods within a longer time interval. This type of analysis enables the identification of changes in the transition probabilities and the interpretation of them as clues to the effects of the external events on persistence.

\section{HYPOTHESES AND RESEARCH DESIGN}

The generation of technological knowledge is an activity characterised by significant indivisibility and learning. Knowledge indivisibility and learning exert strong cumulative effects. Within corporations, the generation of new knowledge and the introduction of innovations are the result of the creation of new functional routines, of research and development laboratories and of the communication networks that allow access to external knowledge. The generation of new knowledge and the related introduction of innovation are shaped by the joint effect of internal cumulative forces and external positive feedback exerted by the system in which firms are embedded.

Therefore, we retain the hypothesis that innovation is a path-dependent, rather than a past-dependent, process determined by several internal and external factors. External factors are characterised by high levels of contingency; as such, their changes affect the dynamics of persistence. Following the resource-based theory of the firm, we suppose that the following factors are important:

A) The size of firms. The generation of technological knowledge is characterised by substantial sunk costs. Corporations that have innovated once are more likely to continue innovating simply because the incremental costs of the internal facilities designed to generate new technological knowledge and introduce innovations are low (Penrose, 1959; Arrow, 1974; Conner and Prahalad, 1996). 
B) The wage level. The well-known dynamics of the Matthew effect are likely to apply not only to scientists but also to firms for at least two reasons. First, it seems plausible that innovating firms are able to pay higher wages and therefore attract more creative and talented employees. Second, innovating firms are likely to interact with innovative suppliers and innovative customers and therefore participate in more fertile and productive user-producer interactions. The repeated interaction between the accumulation of knowledge and the creation of routines to valorise and exploit it eventually leads to the creation of dynamic capabilities that favour the systematic reliance on innovation as a competitive tool (Stiglitz, 1987; Teece and Pisano, 1994; Langlois and Foss, 1999).

C) Price-cost margins. The effects of price-cost margins on the persistence of innovation are twofold. On the one hand, large price-cost margins should provide access to internal funds and favour the innovative efforts of firms; therefore, the effect should be positive. On the other hand, however, large price-cost margins are clear indicators of barriers to entry and market power. Firms that enjoy market power have less incentive to continue funding innovation activities. Therefore, the effects should be negative, especially when the price-cost margin levels are very high (Aghion et al., 2005; Antonelli and Scellato, 2011).

D) The investment in intangible capital. The intangible assets intensity captures firms' efforts to build innovative competencies. R\&D expenditures are the traditional indicator used to measure the internal efforts to generate new technological knowledge. However, R\&D statistics measure only part of the overall effort that firms make to introduce new technologies. Accountancy rules provide suitable evidence of stocks of intangible capital that include capitalised research expenditures, purchasing costs for patents and licences and the costs incurred to build and implement the brand and know-how (Teece, Pisano, Shuen, 1997).

In addition to the internal factors that the literature on innovation persistence has addressed, we argue that external factors play a crucial role. External factors are also contingent because the structure of the system in which external knowledge and rivalry occur change as a result of the introduction of innovations. At each point in time, the networks of interactions and the types of transactions on factor and product markets change. Yet, at each point in time, the architecture of the system and the market exert a strong effect on the ability of firms to access and use external knowledge and to rely on it for the introduction of further innovations as a competitive tool. Because we expect that innovation is a persistent process that occurs when external knowledge and external, local feedback play a 
positive role, we introduce, in addition to the internal factors considered so far, two external factors:

E) The access to local knowledge stock generated by the spillover of other firms' innovative activity provides a key contribution to the persistence of innovative activities. Such effects are typically inter-industrial: knowledge generated in an industry may be useful in other activities (Jacobs, 1969). Hence, we expect that the levels of total factor productivity of firms located in the same region, irrespective of the industrial sector, favour the persistence of innovation. The higher the levels of total factor productivity of all the firms that are co-localized, the higher we expect the innovation persistence to be.

F) The levels of innovative activity of firms within the same industry measure the extent to which the typical Schumpeterian rivalry, based upon the introduction of innovation, is at work. The higher the levels of total factor productivity of rival firms are, the stronger the competitive pressure is. The Schumpeterian rivalry pushes firms to innovate to survive. Therefore, we expect that the higher the efficiency of the rivals within the same industry, the higher the likelihood that each firm relies on the introduction of innovation as a competitive tool and the stronger the persistence of innovation will be (Aghion et al., 2005). These hypotheses are consistent with the model described by Gruber (1992) about the role of sequential product innovations in maintaining leadership in markets characterised by vertical differentiation.

External factors add to internal factors and shape the context in which the persistence of innovation occurs. The external conditions, namely the quality of local pools of knowledge and the strength of the Schumpeterian rivalry, together with the internal conditions (that is, the level of dynamic ability, as proxied by wage levels and firm size), exert a specific and localised effect on the persistent introduction of innovations. Because externalities are internal to the local system in which firms are embedded, the changing conditions exert a path-dependent effect on the sequence of innovations.

To study the persistence of innovation, we rely on a classic indicator such as total factor productivity. We assume that innovation has a much broader scope than indicators focused on the generation and introduction of new, science-based technologies such as patent statistics or aimed at detecting the specific introduction of new products and processes, as measured by innovation counts.

Innovation consists, more generally, of the systematic capability to generate new knowledge and to apply it to the broad array of activities that firms 
engage in. Thus far, our notion of innovation is much broader and retains a strong Schumpeterian flavour because it includes the introduction of new products and new processes as well as the introduction of changes in the organization, in the mix of inputs and in the product and factor markets into which firms operate. Hence, we assume that total factor productivity is better able to capture the general increase in efficiency within a firm that has a good command of technological, organisational and commercial knowledge.

Clearly, our hypothesis here is that the ability to introduce an innovation at time $t+1$ depends on the introduction of an innovation at time $t$ and on the effects of contingent forces that exert themselves locally to affect the sequence of state dependency.

Our two hypotheses lead to a two-step research design. First, we focus our analysis on the determination of innovative activity persistence as measured by Transition Probability Matrixes (TPMs) computed using variations in the levels of total factor productivity. Within the considered time period, we explore the possibility that relevant external factors may affect the transition probabilities. Herein, we introduce the Multiple Transition Probability Matrixes (MTPMs) approach, which consists of analysing sub-period TPMs to test whether transition probabilities change within the time period considered.

The MTPMs involve computing a single Markov chain for the full period of time and comparing those results with the results of computing different Markov chains in the relevant sub-periods. These sub-periods are identified by significant contingent events that are expected to affect the transition probabilities between the innovative and non-innovative status of the analysed companies. We suggest that this approach, based on the comparison of the parameters of the Markov chains in different subperiods, should allow a better identification of the path-dependent character of the innovation process. In particular, the observation of different parameters for the Markov chains in different sub-periods might indicate that the extent of innovation persistence is affected by contingent events and, therefore, that innovation can be qualified as a path-dependent process.

Second, we concentrate the analysis on the determinants of innovation persistence because we want to qualify the type of persistence at work as well as the role of non-observable heterogeneity. Our main argument here is that several contingent and localised conditions, both internal and external to each firm, have a significant effect on the persistence. The persistence of the innovative activity is therefore path-dependent, not past-dependent (David, 1997 and 2007). . 


\section{THE EMPIRICAL EVIDENCE}

\subsection{THE DATA}

Our analysis is based on an original data set containing accounting data for a sample of Italian manufacturing firms. The data set includes financial accounting data for a large sample of manufacturing companies, observed from 1996-2005. The data have been extracted from the AIDA database provided by Bureau Van Dick, which reports accounting information for public and private Italian firms with a turnover larger than 0.5 millions of Euros. The companies included in the analysis were founded before 1995, are registered in a manufacturing sector according to the Italian ATECO classification, and were active at the end of 2005. The introduction of the latter condition implies that we do not consider market exit or entry.

We have included all the companies with at least 15 employees at the end of fiscal year 1995. To drop outliers due to possible errors in the data source, we computed a set of financial ratios and yearly growth rates of employees, sales and fixed capital stock. The final panel is composed of 7020 companies. All financial data have been deflated according to a sectoral twodigit deflator using basic prices from 2000. In annex 1, we report the sectoral composition of the data set.

\subsection{TOTAL FACTOR PRODUCTIVITY AS A MEASURE OF INNOVATION}

We investigate the persistence in innovation activity as measured by firmlevel total factor productivity (TFP). The rate of increase of TFP is a good measure of a firm's degree of innovation. This is especially true in the Italian system where, although the levels of formalised R\&D activities and patenting are low, much innovation is based on informal research activities, tacit knowledge and learning. Hence, we assume that the bottom-line increase in efficiency at the firm level is the ultimate indicator of the wide array of interrelated effects of the introduction of changes in products, processes, markets, organisation and inputs.

To compute firm-level TFP, we first estimated a set of Cobb-Douglas production functions with constant returns to scale for each industry included in the sample to obtain the correct levels of output elasticity for labour and capital. After assigning each firm to an industry, we have 
computed the TFP for company $\mathrm{i}$ in year $\mathrm{t}$ according to the following expression:

$\operatorname{TFP}_{i, t}=\frac{Q_{i, t}}{L_{i, t}^{\beta} K_{i, t}^{1-\beta}}$

Where:

$Q_{i, t} \quad$ :deflated value added

$L_{i, t} \quad$ :number of employees

$K_{i, t} \quad$ :fixed capital stock.

Fixed capital stock has been computed using a perpetual inventory technique according to which the first year accounting data, i.e. year 1996 in our case, are used as actual replacement values. The subsequent yearly values of fixed capital are computed using a depreciation parameter $\delta$, assumed equal to $6.5 \%$, and adding deflated yearly investments. The level of yearly depreciation of physical capital has been chosen following the approach applied in previous studies that have applied perpetual inventory techniques to estimate yearly fixed capital levels adopting depreciation parameters in the range 5\%-10\% for physical capital. On this issue see Olley and Pakes (1996) and Parisi et al. (2006) for the Italian economy. Since the adopted depreciation parameter is constant across industries we should not expect changes in the significance of estimate coefficients for slight changes in $\delta$. The investment parameter $\left(I_{i, t}\right)$ has been computed as the yearly variation in net fixed capital in companies' balance sheets plus yearly amortizations. Hence, the time series of fixed capital is defined as follows:

$$
K_{i, t}=(1-\delta) K_{i, t-1}+I_{i, t} / p_{t}
$$

In order to identify the parameter $\beta$ at industry level to compute equation 2 , we have estimated for each industry the following equation:

$$
\log \left(\frac{Q_{i, t}}{K_{i, t}}\right)=\beta \times \log \frac{L_{i, t}}{K_{i, t}}+\alpha_{i}+\alpha_{t}+\varepsilon_{i, t}
$$

We have used a fixed effect estimator, where $\alpha_{i}$ is a firm specific effect and $\alpha_{t}$ is a time specific effect ${ }^{2}$.

\footnotetext{
${ }^{2}$ For a discussion of the properties of different estimation approaches see Blundell and Bond (2000) and Olley and Pakes (1996).
} 
The following Table 2 provides summary statistics about the variables that will be used in our analyses.

\section{[INSERT TABLE 2]}

\subsection{THE RESERCH STRATEGY TO TEST PATH DEPENDENT INNOVATION PERSISTENCE}

Consistent with the theoretical discussion, our modelling framework follows two complementary approaches. In the first part of the analysis, we investigate the presence of firm-level persistence through multiple transition probability matrixes (MTPMs). In the second part, we explore firm-level innovation persistence through discrete dynamic panel data models. Below, we discuss the methodological details of these complementary approaches.

\subsubsection{The analysis of Multiple Transition Probability Matrixes}

Our analysis aims to identify the path-dependent property that characterises the innovation process. Following an established literature, we rely on transition matrices that have been frequently used to test the hypothesis that history matters in innovation processes (Peters, 2008).

However, previous contributions relied on regular transition matrixes ${ }^{3}$, which imply that the processes under analysis are ergodic. In contrast, to address the non-ergodic character of innovation persistence, we will refer to non-homogeneous Markov chains, which allow us to model time-dependent transition probabilities. Below, we clarify this point and discuss how it affects our empirical approach.

The parameters of transition matrixes can be interpreted as the empirical estimation of an underlying Markov process. More specifically, Markov chains are dynamic, stochastic processes characterised by the presence of discrete values of the states and, more importantly, by the fact that the conditional probability of a state at time $t$ depends exclusively on the state at time $\mathrm{t}-1$. This implies that the process has no memory and that only the last state influences the subsequent state. Technically this amounts to the following definition of state probability along time:

for $t_{k+1}>t_{k}>t_{k-1}>\ldots$

${ }^{3} \mathrm{~A}$ regular TPM is an irreducible matrix with at least one of the diagonal elements different from zero. 


$$
\begin{aligned}
& \operatorname{Pr}\left[X\left(t_{k+1}\right)=x_{t_{k+1}} \mid X\left(t_{k}\right)=x_{t_{k}}, X\left(t_{k-1}\right)=x_{t_{k-1}}, \ldots\right]= \\
& =\operatorname{Pr}\left[X\left(t_{k+1}\right)=x_{t_{k+1}} \mid X\left(t_{k}\right)=x_{t_{k}}\right]
\end{aligned}
$$

Given the above property, all the statistical features of a stationary Markov process can be determined from the conditional densities between two subsequent periods $t_{k}$ and $t_{k+1}$.

$$
f\left(x_{t_{k+1}}, x_{t_{k}}\right)=f\left(x_{t_{k+1}} \mid x_{t_{k}}\right) * f\left(x_{t_{k}}\right)
$$

A Markov process is homogeneous if the conditional density (what we estimate with the TPM) is time-invariant, while the first-order density can vary in time.

If we observe a process that can be described by a TPM, and such matrix is regular, then in the context of Markov chains, we are assuming an underlying stationary ergodic process. In fact, if the underlying process is non-ergodic, it cannot be properly captured by a homogeneous transition matrix.

Suppose that we observe a process in which each company can be in one of just two alternative states at any time: innovative and non-innovative. We then compute - by pooling observations over time - the probability of being in state $i$ at time $t$, conditional on being in state $j$ at time $t-1$, i.e.; we compute a 2X2 TPM. According to the previous considerations, the observation of such a TPM cannot not directly provide evidence of the path-dependent properties of the system based on our definition of path dependency.

The use of regular Markov chains only allows us to state that prior conditions affect future events. Hence, we can say that "history matters" because the innovative status at time $\mathrm{t}$ is not randomly distributed in the population of firms. However, in this setting, all of the past information is incorporated in the state at time $\mathrm{t}-1$. Moreover, the innovation persistence that stems from a time-invariant conditional probability of states is intrinsically ergodic, and it is fully consistent with the hypothesis that innovation persistence is the result of a special quality, a talent, embodied in the firm that qualifies it as a part of the firm's intrinsic endowment. Such innovation persistence is fully consistent with the resource-based theory of the firm where learning internal processes display long-term and stable effects.

Results of previous contributions that have made an implicit use of homogeneous Markov chains (through the computation of a single-period TPM) confirm that the innovation process is a persistent process 
characterised by two features: 1) the (non) introduction of an innovation at time $t$ affects the probability of (not) introducing an innovation at time $t+1$; 2) yet, the estimated structure of probabilities is time-invariant. According to our hypotheses, the innovation process is instead characterised by path dependence. Path dependence takes place when contingent events bear a dynamic effect where the past affects the future with changing transition probabilities. Path-dependent innovation persistence occurs when future events are affected by present ones with changing weights as the contingent events that happen at time t change the transition probability distribution as well. This implies that what we observe by a single-period TPM calculated over a sufficiently long time window is indeed the averaged result of different dynamics in sub-periods.

In the context of economic analysis, we might stretch this consideration to state that for a given change in conditions of the system, external to each firm, but internal to the system in sub-period 1 (e.g., a contraction in credit supply, an increase in aggregated demand, the emergence of new technological opportunities, a change in the provision of external knowledge), the reaction of companies would be captured by the TPM in sub-period 1 and would also affect the TPMs in subsequent sub-periods. A single-period TPM could not grasp these changes. Our approach instead enables the identification and appreciation of the differences between the results of sub-period Markov chains. The observation of different processes in properly defined sub-periods can be interpreted not just as the presence of "transitory" phases toward the long-term stationary process, but also as evidence of path dependence.

\subsubsection{The analysis of persistence through panel data}

While the TPM approach is expected to provide only summary evidence of the path-dependent persistence of firm-level TFP levels over time and a clue about the effects exerted by the changing characteristics of the system, the panel data analysis aims to identify the impact of contingent factors on the persistence of innovation.

To analyse the persistence of innovation over time, we have constructed a time-varying dummy variable $\left(\mathrm{INNO}_{t}\right.$ ) that equals one if a company has experienced a positive TFP growth rate over a two-year period, between year $\mathrm{t}-2$ and year $\mathrm{t}$. We then apply different dynamic discrete choice models in which such a variable is regressed against its past realisation and a set of appropriate controls. In particular, we test the relationship between the innovation dummy variable and both internal and external factors. The former group includes a variable for firm size, measured as the log of a 
firm's total assets (SIZE), an indicator of the level of human capital as captured by the average wage (WAGE), the price-cost-margin as an indicator of a firm's profitability (PCM) and an indicator for the incidence of intangible assets (INTANG), defined as the ratio of intangible to tangible assets in a specific year.

The second group of regressors accounts for changes over time in sectoral technological opportunities and for regional conditions. As previously highlighted, we claim that firms' abilities to introduce technological innovations can be affected by the specific conditions of the local economic environment. For this reason, as controls for external conditions, we include in the model specification a variable (REG_TFP) that for each company $i$ equals the yearly average level of the TFP of all the other companies (included in our sample) and located in the same region as company i. This regressor is expected to capture general regional conditions that potentially affect productivity levels over time, such as the presence of knowledge intensive infrastructure, the local development of financial institutions or specific characteristics in the input markets.

Clearly, changes over time in firm-level TFP are also likely to be affected by non-geographically defined external factors. To account for the sectoral dynamics of TFP, we include in the model the variable SECT_FTP that, for each company $i$, equals the yearly average level of the TFP of all the other companies (included in our sample) in the same 2-digit ATECO classification as company i. Because the innovation dummy variable is defined over a two-year period, we have entered the above mentioned controls into the models with a lag.

As previously highlighted, observed persistence may be a result of true state dependence or permanent unobserved heterogeneity across the analysed companies. From a theoretical perspective, if the source of persistence is permanent unobserved heterogeneity, individuals show a higher propensity to make a decision, but there is no effect of previous choices on current utility, and past experience has no behavioural effect (Heckman, 1981).

In our specific context, we can assume that expected drivers of true state persistence include the existence of dynamic, increasing return to innovation effort, determined by the sunk $\mathrm{R} \& \mathrm{D}$ costs previously incurred by a company, and the internal cumulativity of the innovation process. On the other hand, the source of unobserved, serially correlated characteristics that make firms more or less likely to innovate relate to the risk attitude of entrepreneurs and other idiosyncratic features. By controlling for a set of observable, firm-specific dimensions, we expect to obtain a clearer view of 
the contribution of the different potential sources of the observed innovation persistence.

The baseline specification for a dynamic discrete response model is the following, where $\mathrm{y}_{\text {it }}$ is our innovation indicator:

$y_{i t}^{*}=\gamma y_{i t-1}+\beta x_{i t}+u_{i}+\varepsilon_{i t}$

The estimation of the above model requires an important assumption about the initial observations $y_{i 0}$ and their relationship with $u_{i}$, the unobserved individual effects. In fact, if the start of the analysed process does not coincide with the start of the available observations, $\mathrm{y}_{\mathrm{i} 0}$ cannot be treated as exogenous, and its correlation with the error term would give rise to biased estimates of the autoregressive parameter $g$, which represents our measure of persistence. Two different approaches can be adopted for handling such an initial condition problem. Heckman (1981) suggests specifying the distribution of $\mathrm{y}_{\mathrm{i} 0}$ conditional on $\mathrm{u}_{\mathrm{i}}$ and $\mathrm{x}_{\mathrm{i}}$; alternatively, Wooldridge (2005) proposes specifying the distribution of $\mathrm{u}_{\mathrm{i}}$ conditional on $\mathrm{y}_{\mathrm{i} 0}$ and $\mathrm{x}_{\mathrm{i}}$.

For sake of robustness in our analysis, we have applied both methodologies.

The approach by Heckman (1981) adopts a linearised approximation of the reduced form equation for the initial value $(\mathrm{t}=0)$ of the latent variable as follows:

$y_{i 0}^{*}=z_{i 0} \pi+\eta_{i}$

where $z_{i 0}$ is a vector of exogenous instruments and includes $x_{i 0}$. The underlying assumption of such a specification is that $\eta_{i}$ is correlated with $u_{i}$ (see eq. 5) but uncorrelated with $\varepsilon_{i t}$ for any $\mathrm{t}>0$.

$\eta_{i}=\vartheta u_{i}+\varepsilon_{i 0}$

and

$y_{i 0}^{*}=z_{i 0} \pi+\vartheta u_{i}+\varepsilon_{i 0}$

Given the specification of the initial observation (eq. 4), it is then possible to use the joint probability of the observed binary sequence $(t=0, \ldots t=T)$ with maximum likelihood for the estimation of the dynamic model. Stewart 
(2007) provides an application of this estimator ${ }^{4}$. In our case, we have adopted as instruments in equation (6) firm-level pre-sample variables.

Concerning the Wooldridge modelling approach, we follow the methodology applied by Peters (2009), which offers a simplification of the Wooldridge method using the first realisation of the innovation indicators $\left(\mathrm{y}_{\mathrm{i} 0}\right)$ and the time-averaged covariates as predictors of the individual effect, according to the following relationship:

$$
u_{i}=\alpha_{0}+\alpha_{1} y_{i 0}+\alpha_{2} \bar{x}_{i}+c_{i}
$$

where

$$
\bar{x}_{i}=T^{-1} \sum_{t=1}^{T} x_{i t}
$$

Under the assumption that the error term $\mathrm{c}_{\mathrm{i}}$ is distributed as $N\left(0, \sigma_{c}^{2}\right)$ and that $c_{i} \perp\left(y_{i 0}, \bar{x}_{i}\right)$, we obtain:

$$
u_{i} \mid y_{i 0}, \bar{x}_{i} \approx N\left(\alpha_{0}+\alpha_{1} y_{i 0}+\alpha_{2} \bar{x}_{i}, \sigma_{c}^{2}\right]
$$

Hence, the dynamic probit model can be rewritten according to the following specification:

$$
P\left(y_{i t}=1 \mid y_{i 0}, \ldots, y_{i t-1}, x_{i}, \bar{x}_{i}, c_{i}\right)=\phi\left(\gamma y_{i t-1}+\beta x_{i t}+\alpha_{0}+\alpha_{1} y_{i 0}+\alpha_{2} \bar{x}_{i}+c_{i}\right)
$$

This second methodology, in principle, has the advantage of being less restrictive in terms of exogeneity assumptions than the Heckman methodology. From a technical point of view, the Wooldridge (2005) method amounts to estimating a dynamic random effect probit model in which regressors include a dummy representing the initial realisation of the dependent variable (variable INITIAL in our models) and the time average of those covariates that are expected to be correlated to the individual effect (in our model AVGSIZE, AVGWAGE, AVGPCM, AVGINTANG).

\subsection{RESULTS}

\subsubsection{Evidence from the MTPM analyses}

The following Table 3 provides the results for TPMs obtained on the full sample of companies observed in the entire period (1996-2005) and in the

\footnotetext{
4 The model has been estimated with the STATA routine redprob, developed by Stewart (2007). For more details see http://www2.warwick.ac.uk/fac/soc/economics/staff/faculty/stewart/stata
} 
two sub-periods, before and after 2001. This year has been chosen because it identifies a major contingent event that represented a turning point in the economic cycle during which firms are observed. Moreover, it has the advantage of being in the middle of the panel so that we avoid problems of comparability related to large differences in the sample's dimension. Note that the balanced nature of our firm-level data set avoids possible drawbacks of the TPM analysis.

For each element of the transition probability matrixes, we have also computed standard errors, adopting the following approach. Let $P_{i j}$ and $\hat{P}_{i j}$ denote the population and sample probabilities of a transition of a company from the status $i$ to the status $j$. This transition process can also be viewed as the outcome of a binomial distribution. Hence, standard errors of the estimated transition probabilities can be calculated as a binomial standard deviation, $\sqrt{P_{i j} *\left(1-P_{i j}\right) / N}$, where $\mathrm{N}$ equals the number of companies in status i. As $\mathrm{N}$ increases, $\hat{P}_{i j}$ tends to $P_{i j}$. In the matrixes that will be presented in our analysis, the binomial process clearly has just two possible outcomes. Hence, the estimated standard error is the same for the elements in each row of the $2 \mathrm{X} 2$ matrix.

Our calculations show the presence of strong innovation persistence, as both the main diagonal elements of the transition matrix referring to the whole period are greater than 0.5. However, persistence patterns are found to be different in the two sub-periods. The data show that in the second interval, the percentage of persistent innovators increases from 45.53 to 66.95. The transition probability from a negative to a positive status rises as well, from 27.42 to 35.6. The analysis of the MTPMs offers interesting results. There is a remarkable difference among the results of the three TPMs. This difference confirms that contingent events modify the distribution of transition probabilities, and yet each is statistically significant.

This evidence is quite relevant from both a methodological and a historical viewpoint. From the methodological viewpoint, the high levels of statistical significance of all the matrixes confirm that, in the innovation process, events at time $t$ have a strong effect on the events at time $t+1$. The introduction of an innovation at time $t$ affects the introduction of an innovation at time $\mathrm{t}+1$. At the same time, however, the contingent effects that occurred during the period have significantly changed the 'weight' with which the (non) introduction of an innovation at time $t$ has affected the (non) introduction of an innovation at time $\mathrm{t}+1$.

From the historical viewpoint, this evidence can be easily framed in a Schumpeterian perspective. In the final part of the upturn phase of the 
economic cycle that started in Italy in the second half of 1990s, increasing demand also allowed non-innovative and less-efficient firms to survive in the market, and the incentives to innovate tended to decrease; however, after the turning point, competitive pressure increased, profit margins fell, and the incentives to innovate tended to increase in order for firms to survive. In parallel, a more specific interpretation of the evidence can be linked to the diffusion of ICTs and its economic consequences in Italy, where the rate of penetration of these technologies lagged the USA and other advanced EU countries. This triggered a process of restructuring of production in the early 2000s that might have affected the pace of innovation as measured by positive increments of TFP. Moreover, as evidenced in previous literature (Quatraro, 2009; 2012), the transformation process related to the diffusion of ICT has been uneven in Italy. For this reason, we have split the sample further into 4 macro-regions to identify potential differences in the patterns of innovation persistence across regions and across time. The results indicate that the hierarchy in terms of percentage of persistent innovators is completely inverted in the two subperiods, with north-western Italy showing the greatest presence of persistent innovators after 2001 and southern Italy the lowest. This evidence suggests the presence of a divide. In northern Italy, especially in the north-west, the penetration of ICT activated a virtuous process of transformation in the economy that led the majority of firms to rely on the continuous introduction of innovation as a competitive strategy. However, in southern Italy, there is no evidence of change in the patterns of persistence, indicating that the transformation process that occurred in other parts of Italy has been (at least) less relevant in this case.

This result is important for three reasons. First, it provides original evidence supporting the idea that in the period of observation, an uneven process of transformation in the Italian economy occurred. Second, it supports the hypothesis that the local contexts can contribute to the shaping of patterns of innovation persistence. Third, the evidence suggests that the path- and past-dependent characteristics of innovation persistence can be of varying importance across time and location. In the examined case, in north-western Italy, the path-dependent character of innovation persistence appears to be dominant, while the opposite is true in southern regions.

\section{[INSERT TABLE 3]}

The data seem to provide initial evidence of significant persistence in innovation, as captured by the positive growth rates of TFP. However, we claim that it is important to stress how the above results, although suggesting the presence of some form of inter-temporal stability in 
innovation effort, do not yet provide a sound answer to two key questions: how much of the observed persistence can be labelled as true persistence driven only by previous innovation? Moreover, when internal factors are included in the analysis, to what extent is the observed persistence still influenced by external factors? In the next section, we introduce an econometric analysis specifically devoted to assessing these two issues.

\subsubsection{Results from dynamic panel data analyses}

In Table 4, we report our results for different specifications of the persistence model estimated using the Wooldridge dynamic probit approach. The results show that even after controlling for several internal and external factors, the probability of observing an innovation at time $t$ is positively and significantly affected by the previous realisation of the INNO variable.

\section{[INSERT TABLE 4]}

It is worth clarifying that the result of the econometric analysis tests the effect of several controlling factors on the chances of observing a positive growth rate in TFP, rather than on the probability that innovators keep introducing innovations over time. In this sense, we argue that being located in a region characterised by higher levels of TFP in surrounding firms is positively associated with the probability of introducing some form of innovation. In Table 4, we report the results obtained for the model specification based on the Heckman (1981) approach. In this case, we also find a positive and significant correlation over time in the realisations of the innovation variable. The significance of the other variables is most important because it confirms the path-dependent character of the process. Among the internal factors, the level of human capital, as measured by average unit wage, significantly enhance the probability of subsequent innovation outcomes. The effects of size enter the model specification through two covariates (Table 4): AVGSIZE and SIZE. The former is timeinvariant. The latter is the yearly measure. Our results suggest that the AVGSIZE, i.e., the size class to which each firms belongs, has a negative effect. This result is perfectly aligned with the expectations based upon the Gibrat law. The results suggest, instead, that SIZE, i.e., the time-varying dimension of the firm, has a positive effect. As expected, the intensity of intangible capital, which is a proxy for the investment in research and development and innovation activities over time, exerts a significant positive impact. 


\section{[INSERT TABLE 5]}

In both models (Table 4 and Table 5), the local context exerts a strong and positive effect on the persistence of innovation as measured by the levels of TFP of firms located in the same region. As expected, the access to the local knowledge base and pecuniary knowledge externalities generated by the regional agglomeration of innovative firms favour the persistence of innovative activities. The intensity of innovation among firms active in the same industries also favours the persistence of innovation. The stronger the typical Schumpeterian rivalry among firms that rely on the introduction of innovations as a competitive tool, the stronger the persistence of innovation.

Our results confirm the persistence of total factor productivity growth and suggest that such persistence is affected by contingent factors that are both internal and external to each firm. The results can be interpreted as a test of the claim that persistence is path- rather than past-dependent. Contingent factors, such as human capital, market rivalry and geographic location, would not be significant when persistence is past-dependent because the original conditions would play an exhaustive causal role.

\section{CONCLUSIONS}

Knowledge cumulability, stemming from knowledge indivisibility and knowledge non-exhaustibility, plays a central role in path-dependent innovation persistence. The introduction of further innovations is easier for firms that can command a larger internal knowledge base and have access to larger knowledge bases from nearby firms. Much attention has been paid to the exploration of internal factors that are at the origin of innovation persistence. This paper provides empirical evidence for the central role of external factors in determining the path-dependent persistence of innovation activities, as measured by total factor productivity levels (TFP).

In particular, the paper makes three contributions to the economics of innovation persistence. First, it provides an interpretative framework based on the economics of knowledge that privileges the role of knowledge externalities. Second, it distinguishes between types of innovation persistence. Past-dependent innovation persistence is the result of a given allocation of a specific innovative capability or talent that keeps exerting its effects over time with no changes. Past-dependent innovation persistence is consistent with the predictions of the resource-based theory of the firm. Path-dependent innovation persistence, on the other hand, is the result of 
systemic interaction. Firms caught in out-of-equilibrium conditions in factor and product markets try and react through the introduction of innovations. Their reaction is successful, leading to the introduction of productivityenhancing innovations, only when a set of external conditions are met. Such conditions keep changing over time and affect the likelihood that the introduction of an innovation at time $t$ affects the likelihood that an innovation is also introduced at time $\mathrm{t}+1$.

Third, the paper discusses the methodological implications of the use of a MTPM approach based on the analysis of sub-periods to assess innovation persistence, with specific reference to the Markov chains theory. In particular, we suggest that the comparison of the parameters of different Markov chains across a given stretch of time enables the empirical assessment of whether contingent events have exerted significant effects on persistence patterns. In this case, path-dependent innovation persistence applies because the relationship between past and future is altered by the events that take place at time t. Finally, building on these results, we have investigated the firm-level innovation persistence patterns using dynamic panel methods. The econometric results confirm that the persistence of innovation is affected by contingent and localised events, among which the accessibility of the knowledge stock of nearby agents plays a central role. At each point in time, the probability of the introduction of further innovations is affected by the sequence of innovations introduced in the past. However, the probability also depends on the level of internal dynamic capability of each firm to accumulate and exploit technological knowledge and human capital, the amount of external knowledge that is available in the region, and the competitive pressure of innovative rivals active in the same product markets.

Innovation persistence exhibits the characteristics of path dependence because of the effects of contingent factors that emerge through the process and yet are able to alter its dynamics. Contingent and endogenous changes typically concern the provision and the accessibility of external knowledge that exhibits changing effects over time. External knowledge is possible only if and when effective communication channels based on networks of interactions and transactions are available. The architecture of such networks changes over time, however, because of the conduct of firms and the introduction of innovations. Externalities are external to each firm but internal to the system.

In terms of policy implications, it seems important to stress that the localised, path-dependent character of innovation persistence calls for a systematic and systemic approach to technology policy. In the case of 'pure' state dependence, we would assume that once a firm has been induced to 
innovate, the likelihood that it will keep innovating is enhanced. Therefore, subsequent policy interventions would be redundant. The identification of the central role of external factors in assessing the path dependence of innovation, on the other hand, confirms the need for a national innovation policy to reinforce the internal cumulability of technological knowledge within firms. The role of external factors also stresses the importance of the design and implementation of public interventions devoted to upgrading the architectures of the networks of interactions and transactions at the regional level that can facilitate the provision of external knowledge. The implementation of a twin innovation policy articulated at a national level aimed at firms, especially in sectors where knowledge cumulability is high, and at a regional level, aimed at strengthening the provision of knowledge externalities, is crucial in sustaining the continuous introduction of innovation at the system level.

\section{REFERENCES}

Acs, Z.J., Anselin, L. and Varga, A. 2002. Patents and innovation counts as measures of regional production of new knowledge, Research Policy 31, 1069-1085.

Aghion, P., Bloom, N., Blundell, R., Griffith, R. and Howitt, P. 2005. Competition and innovation An inverted U relationship, Quarterly Journal of Economics 120, 701-28.

Alfranca, O., Rama, R., von Tunzelmann, N. 2002. A patent analysis of global food and beverage firms: The persistence of innovation, Agribusiness 18, $349-368$. 
Antonelli, C. 2008. Localized technological change: Towards the economics of complexity, Routledge, London.

Antonelli C. (Ed.) 2011. Handbook on the economic complexity of technological change, Edward Elgar, Cheltenham.

Antonelli, Scellato, G. 2011. Out of equilibrium, profits and innovation, Economics of Innovation and New Technology 20, 405-421.

Antonelli, C., Scellato, G. 2012. Complexity and innovation: Knowledge interactions and firm level total factor productivity, Journal of Evolutionary Economics, forthcoming

Antonelli C., Crespi F., Scellato G. 2012. Inside innovation persistence: New evidence from Italian micro-data, Structural Change and Economic Dynamics (in press DOI: 10.1016/j.strueco.2012.03.002).

Arellano, M., Bond, S. 1991. Some tests of specification for panel data: Monte Carlo evidence and an application to employment equations, Review of Economic Studies 58, 277-97.

Arrow, K.J. 1974. The limits of organization, W.W. Norton, New York.

Baptista, R. Swann, G.M.P. 1998. Do firms in cluster innovate more?, Research Policy 27 (5), 527-542.

Baptista, R. Swann, G.M.P. 1999. The dynamics of firm growth and entry in industrial clusters: A comparison of the US and UK computer industries, Journal of Evolutionary Economics, 9 (3), 373-399.

Beaudry, C., Swann, G.M.P. 2009. Firm growth in industrial clusters of the United Kingdom, Small Business Economics, 32(4), 409-424.

Blundell R., Bond, S. 1998. Initial conditions and moment restrictions in dynamic panel data models, Journal of Econometrics 87, 115-143.

Cefis, E. 2003. Is there persistence in innovative activities? International Journal of Industrial Organization 21, 489-515.

Cefis, E., Orsenigo, L. 2001. The persistence of innovative activities. A cross-countries and cross-sectors comparative analysis, Research Policy 30, 1139-1158.

Cefis, E., Ciccarelli, M. 2005. Profit differentials and innovation, Economics of Innovation and New Technology 14, 43-61.

Clausen T., Pohjola M., Sapprasert K., Verspagen B. 2011. Innovation strategies as a source of persistent innovation Industrial and Corporate Change, (in press doi:10.1093/icc/dtr051).

Colombelli, A., von Tunzelmann N. 2011. Persistence of innovation and path dependence. In C. Antonelli (ed.) Handbook on the economic complexity of technological change. Edward Elgar, Cheltenham.

Conner, K. R., Prahalad, C.K., 1996. A resource based theory of the firm: Knowledge versus opportunism, Organization Science 7, 477-501.

Crespi F., Pianta M. 2007. Demand and innovation in European industries, Economia Politica-Journal of Analytical and Institutional Economics- n.1 Aprile, pp. 79-112.

David, P. A. 1985. Clio and the economics of QWERTY, American Economic Review 75, 332-37.

David, P.A. 1994. Positive feedbacks and research productivity in science: Reopening another black box, in Granstrand, O. (ed.), The economics of technology, Elsevier North Holland, Amsterdam.

David, P.A. 1997. Path dependence and the quest for historical economics: One more chorus of ballad of QWERTY, Oxford University Economic and Social History Series 020, Economics Group, Nuffield College, University of Oxford.

David, P. A. 2007. Path dependence: A foundational concept for historical social science, Cliometrica: Journal of Historical Economics and Econometric History 1, 91-114 
David, P. A., Rullani, F. 2008. Dynamics of innovation in an "open source" collaboration environment: lurking, laboring, and launching FLOSS projects on SourceForge. Industrial and Corporate Change, 17, 647-710.

Davison, A. C.; Hinkley, D. 2006. Bootstrap methods and their applications, 8th, Cambridge Series in Statistical and Probabilistic Mathematics.

Dosi G. - Freeman C. - Nelson R. - Silverberg G. - Soete L. 1988, Technical change and economic theory, London, Pinter.

Duguet, E., Monjon, S. 2004. Is innovation persistent at the firm level? An econometric examination comparing the propensity score and regression methods, Cahiers de la Maison des Sciences Economiques, Université Panthéon-Sorbonne.

Fagerberg J., Mowery D., Nelson R. (Eds.) 2005. The Oxford handbook of innovation, Oxford, Oxford University Press.

Foster, L., Haltiwanger, J. and C.J. Krizan 2002. The link between aggregate and micro productivity growth: Evidence from retail trade, NBER Working Paper.

Fritsch, M. 2002. Measuring the quality of regional innovation systems: A knowledge production function approach, International Review of Regional Science, 25, 86-101.

Fritsch, M. 2004. Cooperation and the efficiency of regional R\&D activities, Cambridge Journal of Economics, 28, 829-846.

Fritsch, M. and Franke, G. 2004. Innovation, regional knowledge spillovers and R\&D cooperation, Research Policy, 33, 245-255.

Geroski, P. 1994. Market structure corporate performance and innovative activity, Oxford University Press, Oxford.

Griliches Z. 1979. Issues in assessing the contribution of research and development to productivity growth, The Bell Journal of Economics, 10, 92-116.

Gruber, H. 1992. Persistence of leadership in product innovation, Journal of Industrial Economics 40, 359-375.

Heckman, J.J. 1981. The incidental parameters problem and the problem of initial conditions in estimating a discrete time - discrete data stochastic process, in C.F. Manski and D. McFadden (eds.). Structural analysis of discrete data with econometric applications, MIT Press, Cambridge.

Huang, C.H. 2008. A note on the persistence of firms' innovation behavior: A dynamic random effect probit model approach, Economics Bulletin, 15(5), 1-9.

Jacobs, J. 1969. The economy of cities, Random House, New York.

Jang S., Chen J.H., 2011. What determines how long an innovative spell will last? Scientometrics 86, 65-76

Langlois, L.N., Foss, N.J. 1999. Capabilities and governance: The rebirth of production in the theory of organization 52(2), 201-18.

Latham, W.R., Le Bas, C. (eds.) 2006. The economics of persistent innovation: An evolutionary view, Springer, Berlin.

Malerba, F., Orsenigo, L., Petretto, P. 1997. Persistence of innovative activities sectoral patters of innovation and international technological specialization, International Journal of Industrial Organization 15, 801-826.

Martínez-Ros, E. and Labeaga, J. M. 2009. Product and process innovation: Persistence and complementarities, European Management Review 6, 64-75.

Nelson R., Winter S. 1982. An evolutionary theory of economic change, Cambridge (MA), The Belknap Press of Harvard University Press.

Olley S., Pakes, A. 1996. The dynamics of productivity in the telecommunications equipment industry, Econometrica 64, 1263-1297.

Parisi, M.L., Schiantarelli, F., Sembenelli, A. 2006. Productivity innovation and R\&D: Microevidence for Italy, European Economic Review 50, 2037-2061.

Penrose, E., 1959. The theory of the growth of the firm, Oxford University Press, Oxford. 
Peters, B. 2009. Persistence of innovation: Stylized facts and panel data evidence, Journal of Technology Transfer 36, 226-243.

Quatraro, F. 2009. Innovation structural change and productivity growth. Evidence from Italian regions 1980-2003, Cambridge Journal of Economics, 2009, 33, pp. 1001-1022.

Quatraro, F. 2012. The economics of structural change in knowledge, Routledge, London.

Raymond, W., Mohnen, P., Palm, F., Schim van der Loeff, S., 2010. Persistence of innovation in Dutch manufacturing: Is it spurious? Review of Economics and Statistics $92,495-504$.

Roodman, D. 2006. An introduction to "difference" and "system" GMM in Stata, Working Paper n. 103, Center for Global Development. www.cgdev.org

Roper, S., Hewitt-Dundas, N. 2008. Innovation persistence: Survey and case-study evidence, Research Policy 37, 149-162.

Scherer, F.M., Harhoff, D. 2000. Technology policy for a world of skew-distribution outcomes, Research Policy 29, 559-566.

Schumpeter, J. A. 1947. The creative response in economic history, Journal of Economic History 7,149-159.

Stewart, M.B. 2007. The inter-related dynamics of unemployment and low-wage employment, Journal of Applied Econometrics, 22, 511 - 531

Stiglitz, J.E. 1987. Learning to learn localized learning and technological progress, in Dasgupta, P. and Stoneman, P. (eds.), Economic policy and technological performance, Cambridge University Press, Cambridge.

Swann, G.M.P., Prevezer, M., Stout, D.K. 1998. The dynamics of industrial clustering: International comparisons in computing and biotechnology, Oxford University Press, Oxford.

Teece, D.J., Pisano, G. 1994. The dynamic capabilities of firms: An introduction, Industrial and Corporate Change 3, 537-555.

Teece, D.J., Pisano, G., Shuen, A. 1997. Dynamic capabilities and strategic management, Strategic Management Journal 18, 509-533.

Wooldridge, J. 2005. Simple solutions to the initial conditions. Problem in dynamic nonlinear panel data models with unobserved heterogeneity, Journal of Applied Econometrics 20, 39-54.

\section{TABLES}

TABLE 1 Summary of the major contributions to the field of innovation persistence

\begin{tabular}{|c|c|c|c|}
\hline Authors & Data & Methodology & Results \\
\hline & \multicolumn{2}{|c|}{ PATENT DATA ANALYSES } & \\
\hline $\begin{array}{l}\text { Malerba, } \\
\text { Orsenigo and } \\
\text { Peretto (1997) }\end{array}$ & $\begin{array}{l}\text { Patent data from OTAF- } \\
\text { SPRU data base for five } \\
\text { EU countries (1969- } \\
1986)\end{array}$ & $\begin{array}{l}\text { Dynamic } \\
\text { data model }\end{array}$ & \begin{tabular}{llr} 
The & \multicolumn{2}{c}{ econometric } \\
evidence shows that \\
innovative activity is \\
persistent.
\end{tabular} \\
\hline
\end{tabular}




\begin{tabular}{|c|c|c|c|}
\hline 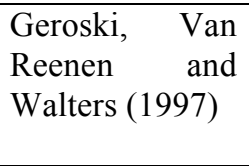 & $\begin{array}{l}\text { Patent records and } \\
\text { 'major' innovations of a } \\
\text { sample of UK firms } \\
(1969-1988)\end{array}$ & $\begin{array}{l}\text { Proportional hazard } \\
\text { function }\end{array}$ & $\begin{array}{l}\text { Only a minority of firms } \\
\text { (major innovators) are } \\
\text { found to be persistently } \\
\text { innovative. }\end{array}$ \\
\hline $\begin{array}{l}\text { Cefis } \quad \text { and } \\
\text { Orsenigo } \\
(2001)\end{array}$ & $\begin{array}{l}\text { Patent data on a sample } \\
\text { of } 1400 \text { manufacturing } \\
\text { firms (1978-1993) in } \\
\text { Germany, Italy, Japan, } \\
\text { US and France }\end{array}$ & $\begin{array}{l}\text { Transition } \\
\text { probability matrix }\end{array}$ & $\begin{array}{lcr}\text { Evidence } & \text { of } & \text { weak } \\
\text { persistence; both low } \\
\text { innovators and great } \\
\text { innovators generally } \\
\text { remain in their classes }\end{array}$ \\
\hline Cefis (2003) & $\begin{array}{l}\text { Data on } 577 \text { UK } \\
\text { patenting firms } \\
\text { 1991) }\end{array}$ & $\begin{array}{l}\text { Transition } \\
\text { probability matrix }\end{array}$ & $\begin{array}{l}\text { Evidence of little } \\
\text { persistence characterised } \\
\text { by a strong threshold } \\
\text { effect. Only great } \\
\text { innovators have a } \\
\text { stronger probability to } \\
\text { keep innovating. }\end{array}$ \\
\hline $\begin{array}{l}\text { Cefis } \\
\text { Ciccarelli } \\
(2005)\end{array}$ & $\begin{array}{l}\text { Data on } 267 \text { UK } \\
\text { patenting firms } \\
\text { 1992) }\end{array}$ & $\begin{array}{l}\text { Bayesian } \\
\text { econometric } \\
\text { models }\end{array}$ & $\begin{array}{l}\text { The study shows that } \\
\text { current innovative } \\
\text { activity can be positively } \\
\text { influenced by past } \\
\text { innovation via the greater } \\
\text { availability of financial } \\
\text { resources. }\end{array}$ \\
\hline $\begin{array}{l}\text { Alfranca, Rama } \\
\text { and von } \\
\text { Tunzelmann } \\
(2002)\end{array}$ & $\begin{array}{l}\text { Information on } 16,698 \\
\text { patents granted in the } \\
\text { United States from } 1977 \\
\text { to } 1994 \text { to } 103 \text { global } \\
\text { firms in the food and } \\
\text { beverage industry. }\end{array}$ & $\begin{array}{l}\text { Time series } \\
\text { analysis }\end{array}$ & $\begin{array}{l}\text { The evidence confirms } \\
\text { that global firms in this } \\
\text { industry exhibit a stable } \\
\text { pattern of technological } \\
\text { accumulation in which } \\
\text { "success breeds success". }\end{array}$ \\
\hline $\begin{array}{l}\text { Latham and Le } \\
\text { Bas (2006) }\end{array}$ & $\begin{array}{l}\text { Patent data for } 3347 \\
\text { French firms }(1969-1985)\end{array}$ & $\begin{array}{l}\text { Duration } \\
\text { econometric model }\end{array}$ & $\begin{array}{l}\text { The persistence of } \\
\text { innovation is stronger } \\
\text { among individuals than } \\
\text { among firms. }\end{array}$ \\
\hline Huang (2008) & $\begin{array}{l}\text { Patent and R\&D data on } \\
246 \text { electronics firms } \\
\text { listed on } \\
\text { the Taiwan Stock } \\
\text { Exchange (1998-2003) }\end{array}$ & $\begin{array}{l}\text { Dynamic random } \\
\text { effect probit model }\end{array}$ & $\begin{array}{l}\text { Evidence supporting the } \\
\text { existence of persistent } \\
\text { innovation after } \\
\text { controlling for firm } \\
\text { heterogeneity. }\end{array}$ \\
\hline $\begin{array}{l}\text { Jang and Chen } \\
(2011)\end{array}$ & $\begin{array}{l}\text { Patent data on } 125 \\
\text { publicly listed IT firms in } \\
\text { Taiwan } \\
(1990-2001)\end{array}$ & Survival analysis & $\begin{array}{l}\text { Evidence of the state } \\
\text { dependent but transient } \\
\text { nature of the competitive } \\
\text { advantage attributable to } \\
\text { innovative persistence. }\end{array}$ \\
\hline & \multicolumn{2}{|c|}{$\begin{array}{c}\text { SURVEY DATA ANALYSES } \\
\end{array}$} & \\
\hline $\begin{array}{l}\text { Duguet and } \\
\text { Monjon (2004) }\end{array}$ & $\begin{array}{lr}\text { Innovation and } & \text { census } \\
\text { data on } 621 & \text { French firms } \\
\text { operating } & \text { in } \\
\text { manufacturing } & \text { sectors } \\
(1986-1996) & \end{array}$ & $\begin{array}{l}\text { Propensity score } \\
\text { matching models }\end{array}$ & $\begin{array}{l}\text { Strong evidence of } \\
\text { innovation persistence } \\
\text { associated with size and } \\
\text { formal R\&D activities. }\end{array}$ \\
\hline $\begin{array}{l}\text { Roper and } \\
\text { Hewitt-Dundas } \\
(2008)\end{array}$ & $\begin{array}{l}\text { Data on } 3604 \text { plants } \\
\text { covered by the Irish } \\
\text { Innovative Panel (1991- } \\
\text { 2002) }\end{array}$ & $\begin{array}{l}\text { Transition } \\
\text { probability matrix }\end{array}$ & $\begin{array}{l}\text { Both product and process } \\
\text { innovations are found to } \\
\text { be strongly persistent. }\end{array}$ \\
\hline Peters (2009) & $\begin{array}{l}\text { Community Innovation } \\
\text { Survey (CIS) data on } \\
\text { German manufacturing } \\
\text { and service firms (1994- } \\
2002 \text { ) }\end{array}$ & $\begin{array}{l}\text { Transition } \\
\text { probability matrix } \\
\text { and dynamic probit } \\
\text { models }\end{array}$ & $\begin{array}{l}\text { High levels of persistence } \\
\text { in undertaking innovation } \\
\text { activities. }\end{array}$ \\
\hline
\end{tabular}




\begin{tabular}{|c|c|c|c|}
\hline $\begin{array}{l}\text { Martínez-Ros } \\
\text { and Labeaga } \\
(2009)\end{array}$ & $\begin{array}{l}\text { ESEE survey on Spanish } \\
\text { manufacturing firms } \\
(1990-1999)\end{array}$ & $\begin{array}{l}\text { Random effect } \\
\text { probit models }\end{array}$ & $\begin{array}{l}\text { Evidence of persistence } \\
\text { with relevant } \\
\text { complementarities } \\
\text { between product and } \\
\text { process innovation. }\end{array}$ \\
\hline $\begin{array}{l}\text { Raymond et al. } \\
(2010)\end{array}$ & $\begin{array}{l}\text { Unbalanced panel of } \\
2,764 \text { enterprises from } \\
\text { the Dutch Community } \\
\text { Innovation } \\
(1994-2000) \text { Surveys }\end{array}$ & $\begin{array}{l}\text { Maximum } \\
\text { likelihood } \\
\text { dynamic } \\
\text { models }\end{array}$ & $\begin{array}{l}\text { The study finds true } \\
\text { persistence in the } \\
\text { probability of innovating } \\
\text { in high-tech industries } \\
\text { and spurious persistence } \\
\text { in the low-tech category. }\end{array}$ \\
\hline $\begin{array}{l}\text { Clausen et al. } \\
(2011)\end{array}$ & $\begin{array}{lr}\text { Panel } & \text { database } \\
\text { constructed } & \text { from R\&D } \\
\text { and } & \text { Community } \\
\text { Innovation } & \text { Surveys in } \\
\text { Norway } & \end{array}$ & $\begin{array}{lr}\text { Dynamic } & \text { random } \\
\text { effects } & \text { probit } \\
\text { models } & \end{array}$ & $\begin{array}{l}\text { R\&D-intensive and } \\
\text { science-based companies } \\
\text { are found to be more } \\
\text { likely to be persistent } \\
\text { innovators. }\end{array}$ \\
\hline $\begin{array}{l}\text { Le Bas et al. } \\
(2011)\end{array}$ & $\begin{array}{l}\text { Panel data on } 287 \text { firms } \\
\text { from } \quad \text { Luxembourg } \\
(\text { CIS2006, 2008) }\end{array}$ & $\begin{array}{l}\text { Multinomial probit } \\
\text { models }\end{array}$ & $\begin{array}{l}\text { Organisational innovation } \\
\text { is shown to be a } \\
\text { determinant factor for } \\
\text { innovation persistence. }\end{array}$ \\
\hline $\begin{array}{l}\text { Antonelli, } \\
\text { Crespi and } \\
\text { Scellato (2012) }\end{array}$ & $\begin{array}{l}\text { Data on } 451 \text { Italian } \\
\text { manufacturing companies } \\
\text { observed during the years } \\
\text { 1998-2006 }\end{array}$ & $\begin{array}{l}\text { Transition } \\
\text { probability matrix } \\
\text { and dynamic probit } \\
\text { model }\end{array}$ & $\begin{array}{l}\text { Clearer evidence of } \\
\text { persistence in the case of } \\
\text { product innovation with } \\
\text { respect to process } \\
\text { innovation when } \\
\text { complementarity effects } \\
\text { are taken into account. }\end{array}$ \\
\hline
\end{tabular}

Table 2 - Definition and summary statistics. All reported variables are timevarying. Financial variables are deflated using year 2000 basic prices.

\begin{tabular}{|l|l|c|c|c|c|c|}
\hline Variable & Definition & Mean & Median & Std err. & $1^{\text {st }}$ perc & $99^{\text {th }}$ perc \\
\hline SIZE & $\begin{array}{l}\text { Log(Total Assets) } \\
\text { computed with perpetual } \\
\text { inventory method }\end{array}$ & 14.351 & 14.390 & 1.387 & 11.011 & 17.741 \\
\hline WAGE & Log (Labour costs/number & 10.307 & 10.232 & 0.248 & 9.744 & 11.015 \\
\hline
\end{tabular}




\begin{tabular}{|l|l|c|c|c|c|c|}
\hline & of employees) & & & & & \\
\hline PCM & Price-cost-margin & 0.285 & 0.279 & 0.256 & 0.056 & 0.671 \\
\hline INNO & $\begin{array}{l}\text { Dummy } 1 \text { in year t if } \\
\text { TFP }_{\mathrm{t}} \text {-TFP } \\
\mathrm{t}-2\end{array}$ & 0.401 & 0 & 0.490 & 0 & 1 \\
\hline REG_TFP & $\begin{array}{l}\text { Ratio of intangible to } \\
\text { tangible assets }\end{array}$ & 0.158 & 0.080 & 0.194 & 0 & 0.858 \\
\hline SECT_TFP & $\begin{array}{l}\text { Average of the log of TFP } \\
\text { of all companies in the } \\
\text { same region of firm i } \\
\text { excluding the contribution } \\
\text { of firm i }\end{array}$ & 8.327 & 8.350 & 0.162 & 7.857 & 8.623 \\
\hline & $\begin{array}{l}\text { Average of the log of TFP } \\
\text { of all companies in the } \\
\text { same sector of firm i, } \\
\text { excluding the contribution } \\
\text { of firm i }\end{array}$ & 8.146 & 8.367 & 0.712 & 5.764 & 9.204 \\
\hline
\end{tabular}

Table3 - Transition probability matrixes for different sub samples and time periods. Standard errors in parentheses.

\begin{tabular}{|l|l|l|}
\hline All period & & \\
\hline & $\begin{array}{l}\text { INNO } \\
\text { t }\end{array}$ & $\begin{array}{l}\text { NOT } \\
\text { INNOt }\end{array}$ \\
\hline INNOt-1 & $\begin{array}{r}57.95 \\
\%\end{array}$ & $42.05 \%$ \\
\hline & $\begin{array}{r}(0.00 \\
4)\end{array}$ & $(0.004)$ \\
\hline
\end{tabular}

\begin{tabular}{|l|r|l|}
\hline \multicolumn{3}{|l|}{ Before 2001 } \\
\hline & $\begin{array}{l}\text { INNO } \\
\mathrm{t}\end{array}$ & $\begin{array}{l}\text { NOT } \\
\text { INNOt }\end{array}$ \\
\hline INNOt-1 & $\begin{array}{r}45.53 \\
\%\end{array}$ & $54.67 \%$ \\
\hline & $\begin{array}{r}(0.00 \\
6)\end{array}$ & $(0.006)$ \\
\hline
\end{tabular}

\begin{tabular}{|l|l|l|}
\hline \multicolumn{2}{|l|}{ After 2001 } \\
\hline & $\begin{array}{l}\text { INNO } \\
\mathrm{t}\end{array}$ & $\begin{array}{l}\text { NOT } \\
\text { INNOt }\end{array}$ \\
\hline INNOt-1 & $\begin{array}{r}66.95 \\
\%\end{array}$ & $33.05 \%$ \\
\hline & $\begin{array}{r}(0.00 \\
5)\end{array}$ & $(0.005)$ \\
\hline
\end{tabular}




\begin{tabular}{|l|r|r|} 
NOT & 32.04 & \\
INNOt-1 & $\%$ & $67.96 \%$ \\
\hline & $(0.00$ & \\
& $3)$ & $(0.003)$ \\
\hline
\end{tabular}

\section{Companies located in North-west}

Before 2001

\begin{tabular}{|l|l|l|}
\hline & $\begin{array}{l}\text { INNO } \\
\mathrm{t}\end{array}$ & $\begin{array}{l}\text { NOT } \\
\text { INNOt }\end{array}$ \\
\hline & $\begin{array}{r}43.06 \\
\%\end{array}$ & $56.94 \%$ \\
\hline & $(0.00$ & \\
& $8)$ & $(0.008)$ \\
\hline NOT & 25.50 & \\
INNOt-1 & $\%$ & $74.50 \%$ \\
\hline & $(0.00$ & \\
& $5)$ & $(0.005)$ \\
\hline
\end{tabular}

After 2001

\begin{tabular}{|l|l|l|}
\hline & $\begin{array}{l}\text { INNO } \\
\mathrm{t}\end{array}$ & $\begin{array}{l}\text { NOT } \\
\text { INNOt }\end{array}$ \\
\hline & $\begin{array}{r}70.17 \\
\%\end{array}$ & $29.83 \%$ \\
\hline & $(0.00$ & \\
& $6)$ & $(0.006)$ \\
\hline NOT & 36.15 & \\
INNOt-1 & $\%$ & $63.85 \%$ \\
\hline & $(0.00$ & \\
& $5)$ & $(0.005)$ \\
\hline
\end{tabular}

\section{Companies located in central regions}

Before 2001

\begin{tabular}{|l|r|l|}
\hline & $\begin{array}{l}\text { INNO } \\
\mathrm{t}\end{array}$ & $\begin{array}{l}\text { NOT } \\
\text { INNOt }\end{array}$ \\
\hline & $\begin{array}{r}48.55 \\
\%\end{array}$ & $51.45 \%$ \\
\hline & $(0.01$ & \\
& $5)$ & $(0.015)$ \\
\hline NOT & 31.29 & \\
INNOt-1 & $\%$ & $68.71 \%$ \\
\hline & $(0.01$ & \\
& $0)$ & $(0.010)$ \\
\hline
\end{tabular}

After 2001

\begin{tabular}{|l|r|l|}
\hline & $\begin{array}{l}\text { INNO } \\
\mathrm{t}\end{array}$ & $\begin{array}{l}\text { NOT } \\
\text { INNOt }\end{array}$ \\
\hline INNOt-1 & $\begin{array}{r}61.97 \\
\%\end{array}$ & $38.03 \%$ \\
\hline & $(0.01$ & \\
& $2)$ & $(0.012)$ \\
\hline NOT & $\begin{array}{r}33.74 \\
\text { INNOt-1 }\end{array}$ & $66.26 \%$ \\
\hline & $(0.00$ & \\
& $9)$ & $(0.009)$ \\
\hline
\end{tabular}

\begin{tabular}{|l|r|r|} 
NOT & 27.42 & \\
INNOt-1 & $\%$ & $72.58 \%$ \\
\hline & $(0.00$ & \\
& $4)$ & $(0.004)$ \\
\hline
\end{tabular}

\begin{tabular}{|l|r|r|} 
NOT & 35.60 & \\
INNOt-1 & $\%$ & $64.40 \%$ \\
\hline & $(0.00$ & \\
& $4)$ & $(0.004)$ \\
\hline
\end{tabular}

\begin{tabular}{|c|c|c|}
\hline \multicolumn{3}{|c|}{$\begin{array}{c}\text { Companies located in } \\
\text { North-est }\end{array}$} \\
\hline \multicolumn{3}{|c|}{ Before 2001} \\
\hline & $\begin{array}{l}\text { INNO } \\
\mathrm{t}\end{array}$ & $\begin{array}{l}\text { NOT } \\
\text { INNOt }\end{array}$ \\
\hline \multirow[t]{2}{*}{ INNOt-1 } & $\begin{array}{r}45.00 \\
\%\end{array}$ & $55.00 \%$ \\
\hline & $\begin{array}{r}(0.01 \\
0) \\
\end{array}$ & $(0.010)$ \\
\hline \multirow[t]{2}{*}{ INNOt-1 } & $\begin{array}{r}27.45 \\
\%\end{array}$ & $72.55 \%$ \\
\hline & $\begin{array}{r}(0.00 \\
6) \\
\end{array}$ & $(0.006)$ \\
\hline \multicolumn{3}{|c|}{ After 2001} \\
\hline & $\begin{array}{l}\text { INNO } \\
\mathrm{t}\end{array}$ & $\begin{array}{l}\text { NOT } \\
\text { INNOt }\end{array}$ \\
\hline \multirow[t]{2}{*}{ INNOt-1 } & $\begin{array}{r}65.98 \\
\% \\
\end{array}$ & $34.02 \%$ \\
\hline & $\begin{array}{r}(0.00 \\
8) \\
\end{array}$ & $(0.008)$ \\
\hline \multirow[t]{2}{*}{ INNOt-1 } & $\begin{array}{r}35.52 \\
\% \\
\end{array}$ & $64.48 \%$ \\
\hline & $\begin{array}{r}(0.00 \\
6)\end{array}$ & $(0.006)$ \\
\hline
\end{tabular}

\begin{tabular}{|c|c|c|}
\hline \multicolumn{3}{|c|}{$\begin{array}{c}\text { Companies located in } \\
\text { South } \\
\end{array}$} \\
\hline \multicolumn{3}{|c|}{ Before 2001} \\
\hline & $\begin{array}{l}\text { INNO } \\
t\end{array}$ & \begin{tabular}{|l} 
NOT \\
INNOt
\end{tabular} \\
\hline \multirow[t]{2}{*}{ INNOt-1 } & $\begin{array}{r}58.14 \\
\%\end{array}$ & $48.86 \%$ \\
\hline & $\begin{array}{r}(0.02 \\
5) \\
\end{array}$ & $(0.025)$ \\
\hline \multirow[t]{2}{*}{ INNOt-1 } & $\begin{array}{r}38.49 \\
\% \\
\end{array}$ & $61.51 \%$ \\
\hline & $\begin{array}{r}(0.02 \\
1) \\
\end{array}$ & $(0.021)$ \\
\hline \multicolumn{3}{|c|}{ After 2001} \\
\hline & $\begin{array}{l}\text { INNO } \\
\mathrm{t}\end{array}$ & \begin{tabular}{|l|} 
NOT \\
INNOt
\end{tabular} \\
\hline \multirow[t]{2}{*}{ INNOt-1 } & $\begin{array}{r}58.63 \\
\% \\
\end{array}$ & $41.37 \%$ \\
\hline & $\begin{array}{r}(0.01 \\
2) \\
\end{array}$ & $(0.012)$ \\
\hline \multirow[t]{2}{*}{ INNOt-1 } & $\begin{array}{r}36.23 \\
\%\end{array}$ & $63.77 \%$ \\
\hline & $\begin{array}{r}(0.00 \\
9) \\
\end{array}$ & $(0.009)$ \\
\hline
\end{tabular}


Table 4 Dynamic random effect probit model with the Wooldridge specification. Dependent variable INNO .

\begin{tabular}{|c|c|c|c|c|}
\hline & MODEL I & MODEL II & MODEL III & MODEL IV \\
\hline L.INNO & $\begin{array}{c}0.668 * * * \\
(0.014)\end{array}$ & $\begin{array}{c}0.668 * * * \\
(0.014)\end{array}$ & $\begin{array}{c}0.650 * * * \\
(0.014)\end{array}$ & $\begin{array}{c}0.650 * * * \\
(0.014)\end{array}$ \\
\hline L.SIZE & $\begin{array}{c}0.048 * * * \\
(0.015)\end{array}$ & $\begin{array}{c}0.048 * * * \\
(0.015)\end{array}$ & $\begin{array}{c}0.047 * * * \\
(0.015)\end{array}$ & $\begin{array}{c}0.047 * * * \\
(0.015)\end{array}$ \\
\hline L.PCM & $\begin{array}{c}0.002 \\
(0.003)\end{array}$ & $\begin{array}{c}0.001 \\
(0.003)\end{array}$ & $\begin{array}{c}0.002 \\
(0.003)\end{array}$ & $\begin{array}{c}0.002 \\
(0.003)\end{array}$ \\
\hline L.WAGE & $\begin{array}{c}0.548 * * * \\
(0.043)\end{array}$ & $\begin{array}{c}0.552 * * * \\
(0.043)\end{array}$ & $\begin{array}{c}0.619 * * * \\
(0.043)\end{array}$ & $\begin{array}{c}0.621 * * * \\
(0.043)\end{array}$ \\
\hline L.INTANG & $\begin{array}{c}0.150 * * \\
(0.059)\end{array}$ & $\begin{array}{c}0.149 * * \\
(0.059)\end{array}$ & $\begin{array}{c}0.155^{* * * *} \\
(0.059)\end{array}$ & $\begin{array}{c}0.155^{* * *} * \\
(0.059)\end{array}$ \\
\hline REG_TFP & & $\begin{array}{c}0.203 * * * \\
(0.062)\end{array}$ & & $\begin{array}{c}0.127 * * \\
(0.062)\end{array}$ \\
\hline SECT_TFP & & & $\begin{array}{c}0.335 * * * \\
(0.013)\end{array}$ & $\begin{array}{c}0.334 * * * \\
(0.013)\end{array}$ \\
\hline AVGWAGE & $\begin{array}{c}0.489 * * * \\
(0.055)\end{array}$ & $\begin{array}{c}0.467 * * * \\
(0.055)\end{array}$ & $\begin{array}{c}0.562 * * * \\
(0.055)\end{array}$ & $\begin{array}{c}0.547 * * * \\
(0.056)\end{array}$ \\
\hline AVGSIZE & $\begin{array}{c}-0.036 * * \\
(0.016)\end{array}$ & $\begin{array}{c}-0.035^{* *} \\
(0.016)\end{array}$ & $\begin{array}{c}-0.036 * * \\
(0.016)\end{array}$ & $\begin{array}{c}-0.035 * * \\
(0.016)\end{array}$ \\
\hline AVGPCM & $\begin{array}{l}-0.008 \\
(0.009)\end{array}$ & $\begin{array}{l}-0.007 \\
(0.009)\end{array}$ & $\begin{array}{l}-0.008 \\
(0.009)\end{array}$ & $\begin{array}{l}-0.007 \\
(0.009)\end{array}$ \\
\hline AVGINTANG & $\begin{array}{c}0.047 \\
(0.074)\end{array}$ & $\begin{array}{c}0.049 \\
(0.074)\end{array}$ & $\begin{array}{c}0.051 \\
(0.074)\end{array}$ & $\begin{array}{c}0.053 \\
(0.075)\end{array}$ \\
\hline INITIAL & $\begin{array}{c}0.077 * * * \\
(0.013)\end{array}$ & $\begin{array}{c}0.075 * * * \\
(0.013)\end{array}$ & $\begin{array}{c}0.073 * * * \\
(0.014)\end{array}$ & $\begin{array}{c}0.071 \text { *** } \\
(0.014)\end{array}$ \\
\hline $\begin{array}{l}\text { Industry dummy } \\
\text { Year dummy } \\
\text { Constant }\end{array}$ & $\begin{array}{c}\text { yes } \\
\text { yes } \\
-11.066^{* * *} \\
(3.619)\end{array}$ & $\begin{array}{c}\text { yes } \\
\text { yes } \\
-11.964 * * \\
(5.704)\end{array}$ & $\begin{array}{c}\text { yes } \\
\text { yes } \\
-10.512 * * * \\
(2.841)\end{array}$ & $\begin{array}{c}\text { yes } \\
\text { yes } \\
-11.870 * * \\
(5.628)\end{array}$ \\
\hline $\begin{array}{l}\text { Observations } \\
\text { Wald Chi-sq } \\
\text { Log likelihood } \\
\end{array}$ & $\begin{array}{c}49140 \\
8661.2 * * * \\
-28540.4 \\
\end{array}$ & $\begin{array}{c}49140 \\
8665.7 * * * \\
-28535.5 \\
\end{array}$ & $\begin{array}{c}49140 \\
9073.4 * * * \\
-28225.3 \\
\end{array}$ & $\begin{array}{c}49140 \\
9087.4 * * * \\
-28223.5 \\
\end{array}$ \\
\hline
\end{tabular}


Table 5 - Dynamic random effect probit model with the Heckman approach. Dependent variable: INNOt. Model estimated with the redprob routine by Stewart (2007). Instruments for reduced form: presample levels of firm-level variables.

\begin{tabular}{|c|c|c|c|c|}
\hline & MODEL I & MODEL II & MODEL III & MODEL IV \\
\hline L.INNO & $\begin{array}{c}0.624 * * * \\
(0.013)\end{array}$ & $\begin{array}{c}0.626^{* * *} \\
(0.013)\end{array}$ & $\begin{array}{c}0.604 * * * \\
(0.013)\end{array}$ & $\begin{array}{c}0.605 * * * \\
(0.013)\end{array}$ \\
\hline L.SIZE & $\begin{array}{c}0.021 * * * \\
(0.005)\end{array}$ & $\begin{array}{c}0.023 * * * \\
(0.005)\end{array}$ & $\begin{array}{c}0.022 * * * \\
(0.005)\end{array}$ & $\begin{array}{c}0.023 * * * \\
(0.005)\end{array}$ \\
\hline L.PCM & $\begin{array}{c}-0.278 * * * \\
(0.023)\end{array}$ & $\begin{array}{c}-0.272 * * * \\
(0.023)\end{array}$ & $\begin{array}{c}-0.279 * * * \\
(0.023)\end{array}$ & $\begin{array}{c}-0.274 * * * \\
(0.023)\end{array}$ \\
\hline L.WAGE & $\begin{array}{c}0.284 * * * \\
(0.031)\end{array}$ & $\begin{array}{c}0.302 * * * \\
(0.032)\end{array}$ & $\begin{array}{c}0.315 * * * \\
(0.031)\end{array}$ & $\begin{array}{c}0.329 * * * \\
(0.032)\end{array}$ \\
\hline L.INTANG & $\begin{array}{c}0.206 * * * \\
(0.033)\end{array}$ & $\begin{array}{c}0.205^{* * *} \\
(0.033)\end{array}$ & $\begin{array}{c}0.220 * * * \\
(0.033)\end{array}$ & $\begin{array}{c}0.219 * * * \\
(0.033)\end{array}$ \\
\hline REG_TFP & & $\begin{array}{c}0.247 * * * \\
(0.060)\end{array}$ & & $\begin{array}{c}0.185 * * * \\
(0.060)\end{array}$ \\
\hline SECT_TFP & & & $\begin{array}{c}0.327 * * * \\
(0.013)\end{array}$ & $\begin{array}{c}0.326^{* * *} \\
(0.013)\end{array}$ \\
\hline Industry dummy & Yes & Yes & Yes & Yes \\
\hline Year dummy & Yes & Yes & Yes & Yes \\
\hline Constant & $\begin{array}{c}2.983 * * * \\
(0.323)\end{array}$ & $\begin{array}{l}1.098^{*} \\
(0.561)\end{array}$ & $\begin{array}{c}-16.329 * * * \\
(0.798)\end{array}$ & $\begin{array}{c}-17.614 * * * \\
(0.903)\end{array}$ \\
\hline Observations & 49140 & 49140 & 49140 & 49140 \\
\hline Wald Chi-sq & $8141.9 * * *$ & $8155.7 * * *$ & $8759.9 * * *$ & $8766.9^{* * *}$ \\
\hline Log likelihood & -29247 & -29240 & -28938 & -28934 \\
\hline
\end{tabular}


ANNEX A - Sectoral distribution of analysed firms

Table A1- Sectoral distribution of companies included in the sample

\begin{tabular}{|l|c|c|}
\hline Industry Classification & $\begin{array}{c}\text { Number of } \\
\text { companies }\end{array}$ & Percentage \\
\hline Food and beverages & 561 & $8.0 \%$ \\
\hline Textile & 607 & $8.6 \%$ \\
\hline Textile product industry & 212 & $3.0 \%$ \\
\hline Leather and leather products manufacturing & 249 & $3.5 \%$ \\
\hline Wood and wood products manufacturing & 155 & $2.2 \%$ \\
\hline Pulp, paper and paper products manufacturing & 174 & $2.5 \%$ \\
\hline Printing & 193 & $2.7 \%$ \\
\hline Chemical industry & 401 & $5.7 \%$ \\
\hline Plastics and rubber manufacturing & 421 & $6.0 \%$ \\
\hline Non-metallic mineral product manufacturing & 390 & $5.6 \%$ \\
\hline Metallurgy & 275 & $3.9 \%$ \\
\hline Metal products manufacturing & 983 & $14.0 \%$ \\
\hline Mechanical machinery and equipment manufacturing & 1,078 & $15.4 \%$ \\
\hline Computer and electronic manufacturing & 24 & $0.3 \%$ \\
\hline Electrical machinery and equipment manufacturing & 287 & $4.1 \%$ \\
\hline Telecommunication machinery and equipment & 91 & $1.3 \%$ \\
\hline Medical, optical and precision equipment & 143 & $2.0 \%$ \\
\hline Transportation equipment manufacturing & 122 & $1.7 \%$ \\
\hline Other transport equipment manufacturing & 61 & $0.9 \%$ \\
\hline Furniture & 487 & $6.9 \%$ \\
\hline Software & 106 & $1.5 \%$ \\
\hline Total & 7,020 & $100.0 \%$ \\
\hline
\end{tabular}




\section{ANNEX B - Robustness control}

In the following table we report the results for the dynamic probit model using a alternative model specification with a three year lag for the computation of the dummy dependent variable. The main results presented in the paper with the two years time lag are confirmed. As expected, we estimate an overall lower level of persistence from the autoregressive covariate due to the fact that we using a longer time window.

Table B1 - Robustness control. Dynamic probit model using a three years time lag for the computation of the dependent variable (INNO).

\begin{tabular}{|c|c|c|c|c|}
\hline & MODEL I & MODEL II & MODEL III & MODEL IV \\
\hline L.INNO & $\begin{array}{c}0.440 * * * \\
(0.017)\end{array}$ & $\begin{array}{c}0.439 * * * \\
(0.017)\end{array}$ & $\begin{array}{c}0.433 * * * \\
(0.017)\end{array}$ & $\begin{array}{c}0.441 * * * \\
(0.017)\end{array}$ \\
\hline L.SIZE & $\begin{array}{c}0.143 * * * \\
(0.020)\end{array}$ & $\begin{array}{c}0.143 * * * \\
(0.020)\end{array}$ & $\begin{array}{c}0.140 * * * \\
(0.020)\end{array}$ & $\begin{array}{c}0.139 * * * \\
(0.020)\end{array}$ \\
\hline L.PCM & $\begin{array}{c}-0.238 * * * \\
(0.054)\end{array}$ & $\begin{array}{c}-0.236 * * * \\
(0.054)\end{array}$ & $\begin{array}{c}-0.240 * * * \\
(0.054)\end{array}$ & $\begin{array}{c}-0.237 * * * \\
(0.054)\end{array}$ \\
\hline L.WAGE & $\begin{array}{c}2.155^{* * *} * \\
(0.058)\end{array}$ & $\begin{array}{c}2.150 * * * \\
(0.058)\end{array}$ & $\begin{array}{c}1.912 * * * \\
(0.059)\end{array}$ & $\begin{array}{c}1.888^{* * * *} \\
(0.060)\end{array}$ \\
\hline L.INTANG & $\begin{array}{c}0.339 * * * \\
(0.093)\end{array}$ & $\begin{array}{c}0.342^{* * * *} \\
(0.093)\end{array}$ & $\begin{array}{c}0.335^{* * * *} \\
(0.093)\end{array}$ & $\begin{array}{c}0.329 * * * \\
(0.093)\end{array}$ \\
\hline REG_TFP & & $\begin{array}{l}0.157 * * \\
(0.078)\end{array}$ & & $\begin{array}{c}0.155^{* *} \\
(0.079)\end{array}$ \\
\hline SECT_TFP & & & $\begin{array}{c}0.304 * * * \\
(0.161)\end{array}$ & $\begin{array}{c}0.302 * * * \\
(0.161)\end{array}$ \\
\hline AVGWAGE & $\begin{array}{c}1.863 * * * \\
(0.070)\end{array}$ & $\begin{array}{c}1.844 * * * \\
(0.071)\end{array}$ & $\begin{array}{c}1.687 * * * \\
(0.071)\end{array}$ & $\begin{array}{c}1.658 * * * \\
(0.072)\end{array}$ \\
\hline AVGSIZE & $\begin{array}{c}-0.110 * * * \\
(0.021)\end{array}$ & $\begin{array}{c}-0.109 * * * \\
(0.021)\end{array}$ & $\begin{array}{c}-0.110 * * * \\
(0.021)\end{array}$ & $\begin{array}{c}-0.109 * * * \\
(0.021)\end{array}$ \\
\hline AVGPCM & $\begin{array}{l}-0.008 \\
(0.012)\end{array}$ & $\begin{array}{l}-0.008 \\
(0.012)\end{array}$ & $\begin{array}{l}-0.007 \\
(0.011)\end{array}$ & $\begin{array}{l}-0.007 \\
(0.011)\end{array}$ \\
\hline AVGINTANG & $\begin{array}{l}-0.063 \\
(0.075)\end{array}$ & $\begin{array}{l}-0.064 \\
(0.075)\end{array}$ & $\begin{array}{l}-0.052 \\
(0.076)\end{array}$ & $\begin{array}{l}-0.052 \\
(0.076)\end{array}$ \\
\hline INITIAL & $\begin{array}{l}-0.024 \\
(0.016)\end{array}$ & $\begin{array}{l}-0.025 \\
(0.016)\end{array}$ & $\begin{array}{l}-0.022 \\
(0.016)\end{array}$ & $\begin{array}{l}-0.022 \\
(0.016)\end{array}$ \\
\hline $\begin{array}{l}\text { Industry dummy } \\
\text { Year dummy }\end{array}$ & $\begin{array}{c}2.673 * * * \\
(0.517)\end{array}$ & $\begin{array}{l}1.516 * \\
(0.777)\end{array}$ & $\begin{array}{c}-19.035 * * * \\
(1.259)\end{array}$ & $\begin{array}{c}-19.421 * * * \\
(1.369)\end{array}$ \\
\hline Constant & $\begin{array}{c}-6.655^{* * *} \\
(0.586)\end{array}$ & $\begin{array}{c}-6.711 * * * \\
(0.607)\end{array}$ & $\begin{array}{c}-6.615^{* * *} \\
(0.595)\end{array}$ & $\begin{array}{c}-6.195 * * * \\
(0.476)\end{array}$ \\
\hline Observations & 42120 & 42120 & 42120 & 42120 \\
\hline Wald Chi-sq & $8061.1 * * *$ & $8074.8 * * *$ & $8277.3 * * *$ & $8213.4 * * *$ \\
\hline Log likelihood & -19168.4 & -19167.9 & -18991.0 & -18991.2 \\
\hline
\end{tabular}


